J. Clin. Chem. Clin. Biochem.

Vol. 14, 1976, pp. 227-237

\title{
Evaluation of the Abbott Bichromatic Analyzer 100 (A Proposal for an Evaluation Scheme)
}

\author{
By R. Haeckel
}

Technical Assistance: G. Höner, S. Dieterich, O. Sonntag and U. Strewe

Institut für Klinische Chemie

Medizinische Hochschule Hannover

(Received January 21/March 9, 1976)

Summary: This report summarizes a one year evaluation of Abbott's ABA 100, with respect to mechanical parts (syringe plates, precision and linearity of photometry, band width of several filters, multicuvet precision, temperature control) and the reliability of several methods (endpoint procedures: determination of the glucose concentration with the hexokinase- and the glucose dehydrogenase method, and of the protein concentration; enzyme activities: alanine and aspartate aminotransferase, creatine kinase, alkaline phosphatase).

The critical batch size was estimated as an indicator of economy (about 40 samples per day for the glucose concentration).

Various aspects of the instrument are discussed with respect to its use in clinical chemistry.

\section{Evaluation des Abbott Bichromatic Analyzer 100}

\section{Ein Vorschlag für ein Evaluations-Schema}

Zusammenfassung: Der ABA 100 wurde während eines Jahres bezüglich der Mechanik (Syringe plates, Präzision und Linearität des Photometers, Bandbreite einiger Filter, Präzision der Multiküvette, Temperaturkontrolle) und einiger Methoden getestet. Zur analytischen Evaluation wurden 2 Endpunkt-Verfahren (Bestimmung der Glucosekonzentration mittels der Hexokinase- und der Glucosedehydrogenase-Methode und der Proteinkonzentration) und 4 Enzymaktivitätsbestimmungen (Alanin- und Aspartat-Aminotransferase, Creatinkinase, Alkalische Phosphatase) ausgewählt.

Als Indikator für die Wirtšchaftlichkeit des ABA 100 wurde die kritische Serienlänge für die Glucose-Bestimmung auf etwa 40 Proben für eine tägliche Serie gesçhätzt.

Einige Vor- und Nachteile des Gerätes für klinisch-chemische Routinelaboratorien werden diskutiert.

\section{Introduction}

Two years ago the ABA 100, a single channel, discrete analyzer, was introduced on the European market after it has been successfully distributed in the United States since 1971. We undertook a 12 months evaluation because of some features which distinguish this instrument from most other analyzers: the use of 2 wavelengths for each determination, of a polystyrene multicuvet and of an interchangeable syringe plate.

This report contains a minimum of information which should be collected during the evaluation of analyzers. The study follows some recommendations of Broughton et al. (1).

\section{Materials and Methods}

The ABA 100 (serial No. 136 A) was set up according to table 1 as recommended by the manufacturer (Abbott $\mathrm{GmbH}$, D-6236 Eschborn). The analyzer was installed with an air conditioner (serial No. 73 552).

\section{Glucose}

Test kits were used from Abbott (hexokinase method), from Boehringer Mannheim (D-6800 Mannheim, hexokinase method; No. 124346; assay mixture: 200 parts of solution I, 8 parts of II and III, 1.6 parts of IV) and from E. Merck AG (D-6100 Darmstadt, glucose dehydrogenase method, No. 3389; assay mixture: $20 \mathrm{ml}$ buffer-enzyme solution mixed with $0.2 \mathrm{ml}$ NAD solution, $0.22 \mathrm{~mol} / \mathrm{l}$ ). For comparison the glucose concentration was determined with an Eppendorf endpoint 
Tab. 1. Use of the ABA 100 for various methods.

\begin{tabular}{|c|c|c|c|c|c|c|c|c|}
\hline Methods & Filter & $\begin{array}{l}\text { Temper- } \\
\text { ature } \\
{\left[^{\circ} \mathrm{C}\right]}\end{array}$ & $\begin{array}{l}\text { Time } \\
\text { [min] }\end{array}$ & $\begin{array}{l}\text { Carousel } \\
\text { revolution }\end{array}$ & Direction & $\begin{array}{l}\text { Syringe } \\
\text { plate }\end{array}$ & $\begin{array}{l}\text { Mode } \\
\text { Selector }\end{array}$ & Zero \\
\hline $\begin{array}{l}\text { Glucose } \\
\text { Total protein } \\
\text { r-glutamyltransferase } \\
\text { a-hydroxybutyrate dehydro- } \\
\text { genase }\end{array}$ & $\begin{array}{l}340 / 380 \\
550 / 650 \\
450 / 415 \\
340 / 380\end{array}$ & $\begin{array}{l}25 \\
25 \\
25 \\
25\end{array}$ & $\begin{array}{r}5 \\
10 \\
5 \\
5\end{array}$ & $\begin{array}{l}2 \\
2 \\
3 \\
3\end{array}$ & $\begin{array}{l}\text { up } \\
\text { up } \\
\text { down } \\
\text { down }\end{array}$ & $\begin{array}{l}1: 101 \\
1: 51 \\
1: 51 \\
1: 51\end{array}$ & $\begin{array}{l}\text { end point } \\
\text { end point } \\
\text { rate } \\
\text { rate }\end{array}$ & $\begin{array}{l}00.00 \\
000.0 \\
1500 \\
-425\end{array}$ \\
\hline $\begin{array}{l}\text { Lactate dehydrogenase } \\
\text { Alkaline phosphatase } \\
\text { Creatine kinase } \\
\text { Aspartate aminotransferase } \\
\text { p-nitrophenol }\end{array}$ & $\begin{array}{l}340 / 380 \\
450 / 415 \\
340 / 380 \\
340 / 380 \\
450 / 415\end{array}$ & $\begin{array}{l}25 \\
25 \\
25 \\
25 \\
25\end{array}$ & $\begin{array}{l}5 \\
5 \\
5 \\
5 \\
5\end{array}$ & $\begin{array}{l}3 \\
3 \\
3 \\
3 \\
3\end{array}$ & $\begin{array}{l}\text { down } \\
\text { down } \\
\text { down } \\
\text { down } \\
\text { down }\end{array}$ & $\begin{array}{l}1: 101 \\
1: 101 \\
1: 26 \\
1: 26 \\
1: 101\end{array}$ & $\begin{array}{l}\text { rate } \\
\text { rate } \\
\text { rate } \\
\text { rate } \\
\text { end point }\end{array}$ & $\begin{array}{r}-600 \\
1800 \\
1700 \\
-600 \\
1800\end{array}$ \\
\hline
\end{tabular}

analyzer 5030 (Eppendorf Gerätebau GmbH, D-2000 Hamburg) and with a Gemsaec analyzer (Electro-Nucleonnics, D-7000 Stuttgart) as previously described $(2,3)$

The recovery of glucose added to various serum samples was calculated from the results of the following assays:

1. $9.0 \mathrm{ml}$ double distilled $\mathrm{H}_{2} \mathrm{O}+1.0 \mathrm{ml}$ glucose solution $(10$ or $100 \mathrm{mmol} / \mathrm{l})$

2. $9.0 \mathrm{ml}$ serum $+1.0 \mathrm{ml}$ glucose solution $(10$ or $100 \mathrm{mmol} / \mathrm{l})$.

3. $9.0 \mathrm{ml}$ serum $+1.0 \mathrm{ml}$ double distilled $\mathrm{H}_{2} \mathrm{O}$.

\section{Artificial hemolysis}

Blood samples were drawn with heparinized monovettes (W. Sarstedt, D-5223 Nümbrecht-Rommelsdorf) and divided into 2 halves. One part was frozen $\left(-50^{\circ} \mathrm{C}\right)$ for approx. 20 minutes, thawed in a water bath $\left(+37^{\circ} \mathrm{C}\right)$, shaken for 10 minutes (vortex mixer) and then centrifuged (10 minutes, $4000 \mathrm{rpm}$, Christ centrifuge Junior III) together with the untreated other part. The supernatant plasma was used for the determination of the glucose concentration.

\section{Protein}

Boehringer test combination No. 124290 and biuret reagents for the SMA 12/60 from Technicon Corp. (D-6368 Bad Vilbel; method file No. $\mathrm{N}-14 \mathrm{~b}$ ). Sample blank values were obtained with the ABA 100 by using an alkaline iodide solution as diluent (biuret reagent without $\mathrm{CuSO}_{4}$ and tartrate).

\section{Enzyme activities}

were determined for comparison with Eppendorf analyzers 5010 (Eppendorf Gerätebau GmbH) according to the Recommendations of the German Society of Clinical Chemistry (4). International units were calculated from 7 absorbance readings by means of regression analysis (5). Boehringer test combinations were used with the ABA 100, and the following were used with the Eppendorf analyzer:

Creatine kinase Boehringer test combination No. 124176 alkaline phosphatase Merckotest No. 3314, lactate dehydrogenase Merckotest No. 3367, alanine aminotransferase Merckotest No. 3376, aspartate aminotransferase Merckotest No. 3375 and $r$-glutamyltransferase Boehringer test combination No. 124702.

All reagents from test kits were prepared according to the instructions of the manufacturer.

Bilirubin control, lot No. BIC-294 (bilinubin: $19.6 \mathrm{mg} / \mathrm{dl}$, human albumin: $5.5 \mathrm{~g} / \mathrm{dl}$ ) was purchased from Merz \& Dade (D-8000 München).

The band width of some interference filters was determined with a spectrophotometer DMR 21 (C. Zeiss, D-7082 Ober kochen). The filters were held by a self-made adapter (slit: maximal $0.06 \mathrm{~mm}$, scale of registration $0-20 \%$, MT 2-1).
The filter factor was checked for a filter $340 / 380 \mathrm{~nm}$ with the hexokinase procedure for the determination of the glucose concentration: $100 \mathrm{ml}$ reaction mixture $+1 \mathrm{ml}$ glucose standard solution (10 mmol/l); $50 \mu l$ of the total mixture were transferred into eâch cuvet. The "scaling factor" was set to 05.00 and "zero" to 00.00 . The mean of at last 10 print-out values yields the filter factor.

The calculation of precision within series from duplicates and from day to day and other statistical tests were performed as described in 1.c. (6).

\section{Results}

Technical features of the ABA 100 were evaluated first, followed by methodological aspects, which were divided into endpoint determinations (e.g. glucose and protein concentration) and measurements of enzyme activities.

\section{Mechanical evaluation}

\section{Syringe plates}

The syringe plates are designed to dispense fixed volumes. They are easily and rapidly interchanged (10 seconds to turm a screw and to flush the reagent). The correct volumes are set by the manufacturer. The precision of the total volume dispensed by various syringe plates are listed in table 2 .

Tab. 2. Precision of syringe plates dispensing sample and diluent (double distilled water). The temperature was not considered.

\begin{tabular}{lclllll}
\hline $\begin{array}{l}\text { Syringe } \\
\text { plate }\end{array}$ & $\begin{array}{c}\text { sample } \\
\text { volume } \\
{[\mu l]}\end{array}$ & $\begin{array}{l}\text { diluent } \\
\text { volume } \\
{[\mu \mathrm{l}]}\end{array}$ & $\begin{array}{l}\overline{\mathrm{x}} \\
{[\mathrm{mg}]}\end{array}$ & $\mathrm{s}$ & $\mathrm{CV}$ ) & $\mathrm{n}$ \\
\hline $\mathrm{mg}]$ & {$[\%]$} & \\
\hline $1: 201$ & 2.5 & 500 & $5219 \mathrm{~b})$ & 2 & 0.05 & 10 \\
$1: 101$ & 5 & 500 & 493.3 & 0.3 & 0.29 & 10 \\
$1: 51$ & 5 & 250 & 254.4 & 0.3 & 0.11 & 10 \\
$1: 26$ & 10 & 250 & 261.3 & 0.21 & 0.08 & 10 \\
& & & 259.6 & 0.4 & 0.16 & 10 \\
\hline
\end{tabular}

a) coefficient of variation.

b) control serum as sample; in all other cases double distilled water was used. 
Tab. 3. Measurement of absorbance units with an ABA 100 at 8 days using an alkaline $p$-nitrophenol solution $(560 \mathrm{mg} / 1 \mathrm{NaOH}$, $1.0 \mathrm{~mol} / \mathrm{l})$.

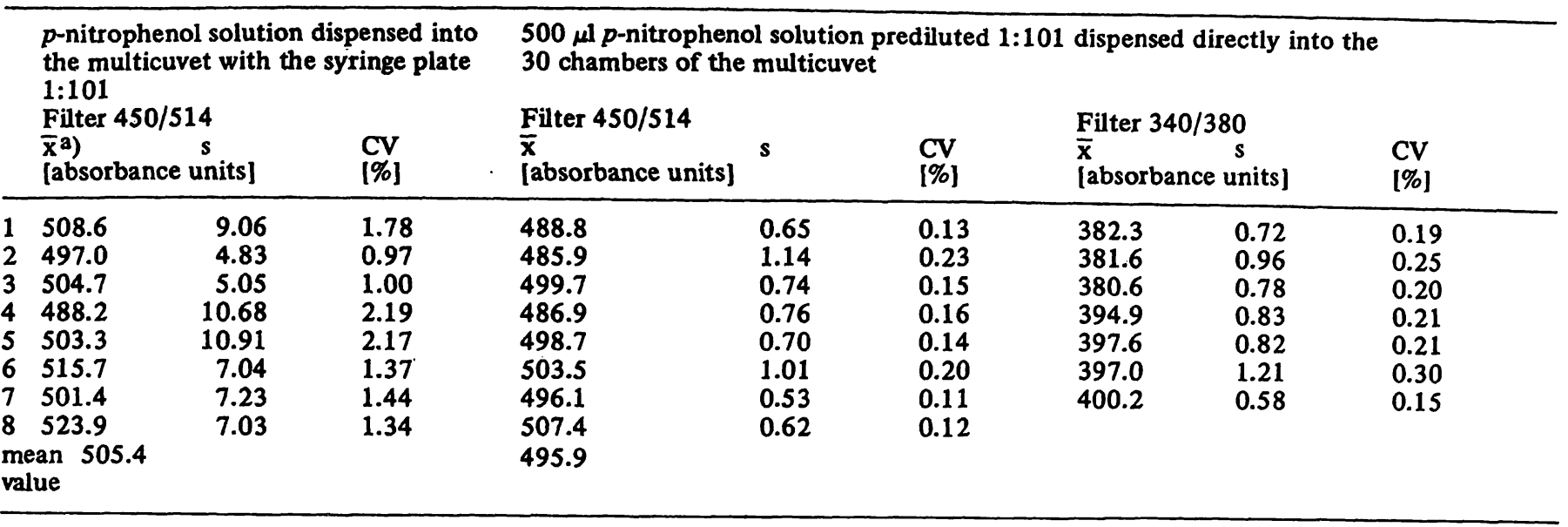

a) mean value of 30 measurements.

For the determination of enzyme activities the volumes should be dispensed as accurately as possible if the calculation factor provided by the manufacturer is applied. The sample volume is too low for exact weighing. Therefore, the dilution of a coloured solution was used to get information on precision and accuracy of the sample pipetting (tab. 3).

The precision of photometry determined with a p-nitrophenol solution prediluted 1:101 (5 ml precision pipet, $500 \mathrm{ml}$ volumetric flask) was found to be about $0.16 \%$, and that of the diluting process of a $1: 101$ syringe plate to be about $1.5 \%$ (tab. 3). The mean values of both procedures from $30 \times 10$ measurements (at 10 days) differed by approximately $2 \%$. Another 1:101 syringe plate was found to be much less accurate. Therefore, the volume dispensed should be checked by the customer if accurate volumes are required.

\section{Multicuvette}

Absorbance differences between single cuvettes are corrected by the dual wavelength mode of the ABA 100. Cross variations of the inner diameter (pathway of the light beam) were not observed (tab. 3).

\section{Temperature control}

The temperature control was checked during 2 weeks at 900 a.m. and 300 p.m. with a platinum resistance thermometer inserted into the water bath and into single cuvettes containing $500 \mu \mathrm{l}$ double distilled water. A mean difference of $0.1^{\circ}{ }^{\circ}$ between the surrounding water bath and the inner room cuvettes was observed. The variations from day to day or between the 2 daily measurements were within the precision of the thermometer $\left(<0.1^{\circ} \mathrm{C}\right)$. The cooling device consists of a fan blowing air around the water bath. This system tolerated a hair dryer positioned in front of the analyzer up to an air temperature of approximately $30^{\circ} \mathrm{C}$ (tab. 4). This is in agreement with the claim of the manufacturer that the air conditioning unit has a capacity up to $30^{\circ} \mathrm{C}$ room temperature.

\section{Photometer}

The precision of photometry at 450 and $340 \mathrm{~nm}$ can be judged from table 3 . During a period of 12 carousel revolutions the print-out value of a $5.5 \mathrm{mg} / \mathrm{l} p$-nitrophenol solution in $0.1 \mathrm{~mol} / \mathrm{l} \mathrm{NaOH}$ (print-out $=0380$; absorbance determined with a Zeiss spectrophotometer PM 4: $\left.\mathbf{A}_{450 \mathrm{~nm}} \sim 0.1, \mathbf{A}_{415} \mathrm{~nm} \sim 0.5\right)$ drifted 6 digits per hour. The linearity of the photometer reading could be followed up to a $p$-nitrophenol concentration of $250 \mu \mathrm{mol} / 1$ at $450 / 415 \mathrm{~nm}$ (fig. 1). This solution has an absorbance of about 2.5 at $415 \mathrm{~nm}$ (Zeiss photometer PM 4). The band width of several interference filters which were selected by chance is reported in table 5. The factors of two $340 / 380 \mathrm{~nm}$ filters were

Tab. 4. The temperature control of the $\mathrm{ABA} 100$ at $25^{\circ} \mathrm{C}$ under the influence of a hair dryer positioned in front of the analyżer. Ten minutes after another temperature was set, the temperature was measured with 2 thermometers at cuvette No. 1 and cuvette No. 18 in the surrounding air and by a platinum resistance thermometer in cuvette No. 1 and No. 18 filled with $500 \mu l$ water.

\begin{tabular}{llll}
\hline $\begin{array}{l}\text { Surround ing air }{ }^{\circ} \mathrm{C} \\
\text { in front of } \\
\text { behind } \\
\text { carousel }\end{array}$ & $\begin{array}{l}\text { Cuvette } \\
\text { carousel }\end{array}$ & No. 1 & No. 18 \\
\hline 21.2 & 18.8 & 24.7 & 24.5 \\
27.8 & 24.4 & 24.6 & 24.6 \\
30.4 & 26.4 & 24.7 & 24.7 \\
35.2 & 28.0 & 25.1 & 25.1 \\
37.4 & 30.6 & 25.7 & 25.7 \\
46.4. & 31.4 & 26.7 & 26.8 \\
\hline
\end{tabular}




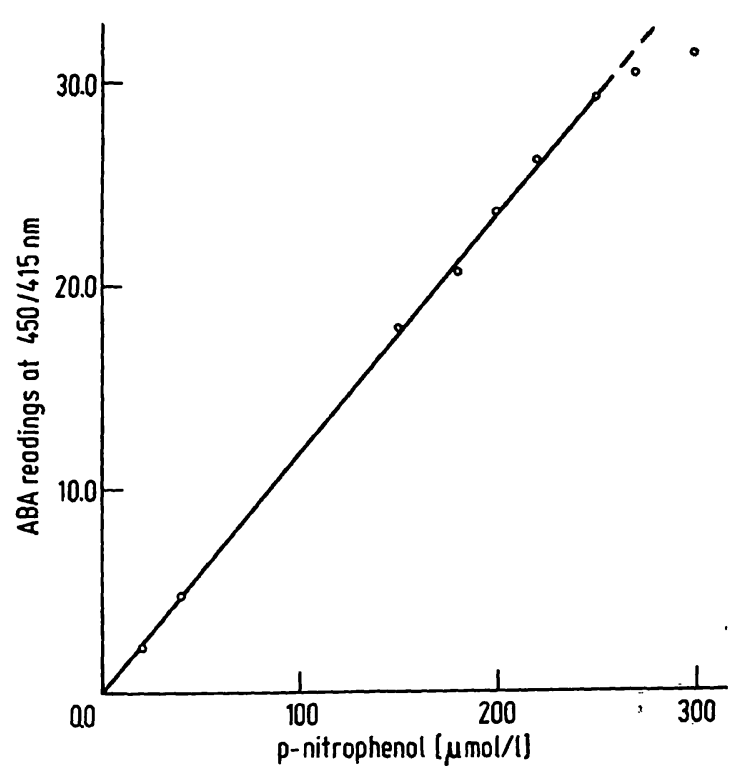

Fig. 1. Linearity of the ABA 100 photometer at $450 / 415 \mathrm{~nm}$.

found to be $1.5-2 \%$ higher than those provided by the manufacturer: 4.58 (Abbott: 4.65) and 4.86 (Abbott: 4.96).

\section{Analytical evaluation}

\section{Glucose}

Two methods for the determination of the glucose concentration were compared with the ABA 100: the hexokinase and the glucose dehydrogenase procedure (7).
Tab. 5. Optical band width of various interference filters supplied with an ABA 100.

\begin{tabular}{llll}
\hline $\begin{array}{l}\text { Filter } \\
\mathrm{nm}\end{array}$ & $\begin{array}{l}\text { band width } \\
\mathrm{nm}^{\mathrm{a}} \text { ) }\end{array}$ & \multicolumn{2}{c}{$\begin{array}{l}\text { maximum of transmission } \\
\text { at } \mathrm{nm}\end{array}$} \\
\hline 500 & 12.0 & 498.5 & 13.7 \\
500 & 12.0 & 497.5 & 15.9 \\
600 & 12.0 & 601.0 & 17.0 \\
600 & 12.0 & 601.5 & 13.8 \\
380 & 10.5 & 380.0 & 11.6 \\
380 & 10.8 & 381.0 & 10.4 \\
340 & 11.5 & 340.0 & 18.8 \\
340 & 12.5 & 340.0 & 19.2 \\
\hline
\end{tabular}

a) double path through the optical system decreases the band width by $\sqrt{2}$.

The instrument was set up in the same way for both methods (tab. 1). Both methods were linear at least up to $20 \mathrm{mmol} / 1$ glucose.

The precision from day to day varied between 1.9 and $4.7 \%$ (tab. 6). The means in table 6 correlated sufficiently with the assigned values.

The accuracy was further investigated by comparing the results from various patients' sera with the ABA 100 and with 2 other analyzers (fig. 2). In the Eppendorf instrument the supernatant from a deproteinization with $\mathrm{Zn}(\mathrm{OH})_{2}$ was used; with the Gemsaec serum samples were directly assayed by a two-point procedure (3).

The ABA 100 applies a dual-wavelength blank-subtraction technique which uses the NADH, or NADPH

Tab. 6. Glucose concentration (mmol/l) found in various control sera with the hexokinase and the glucose dehydrogenase method.

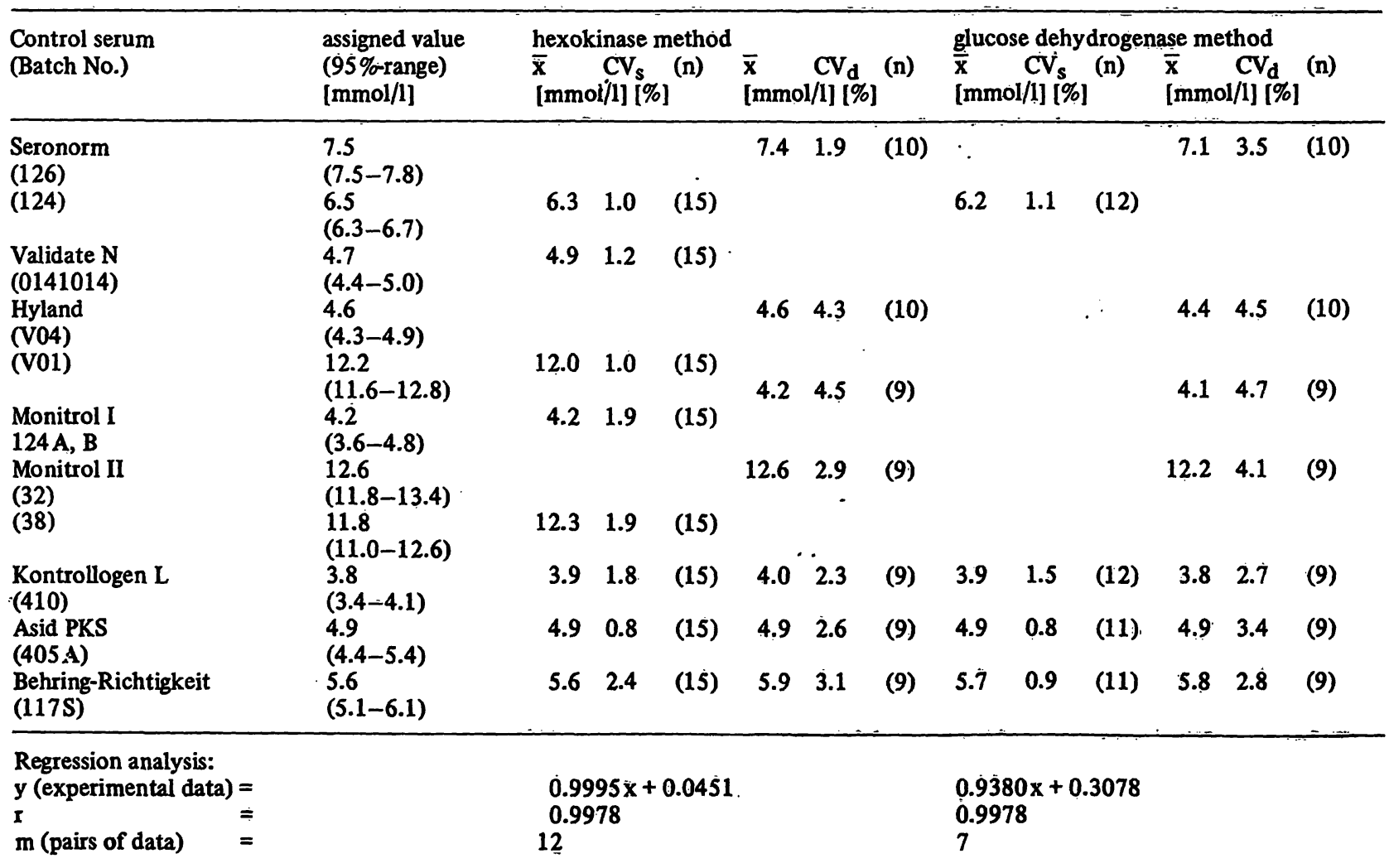



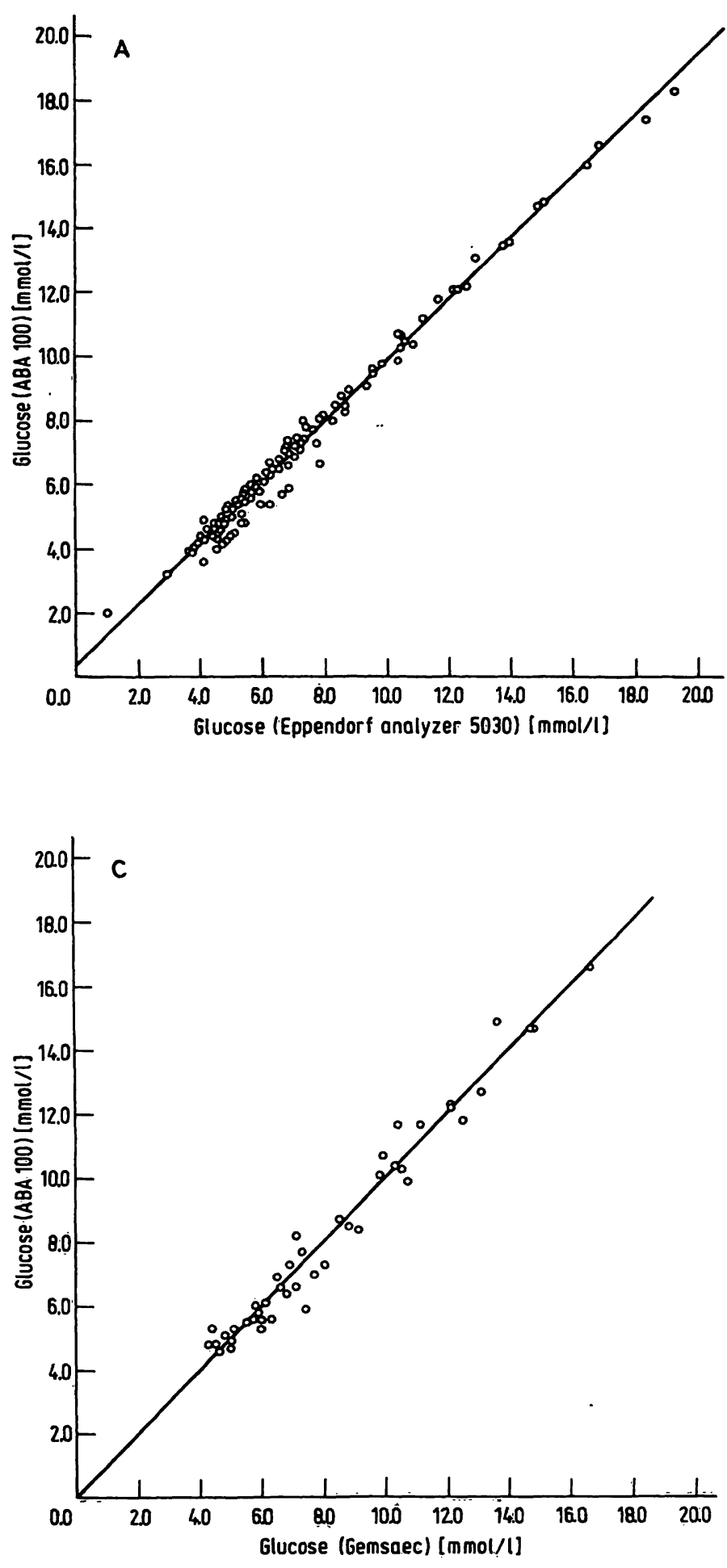

absorbance maximum at $\mathbf{3 4 0} \mathrm{nm}$ corrected for background absorbance at $\mathbf{3 8 0} \mathrm{nm}$. Over-or undercorrection could produce false results. Therefore, the influence of hemoglobin, triglycerides and bilirubin on both glucose methods wàs investigated.

Gochman et al. (8), using the ABA 100, did not observe interference in the glucose determination by hemoglobin. This could be confirmed up to a concentration of about $1 \mathrm{~g} / \mathrm{l}$ hemoglobin. With $3 \mathrm{~g} / 1$ a slight

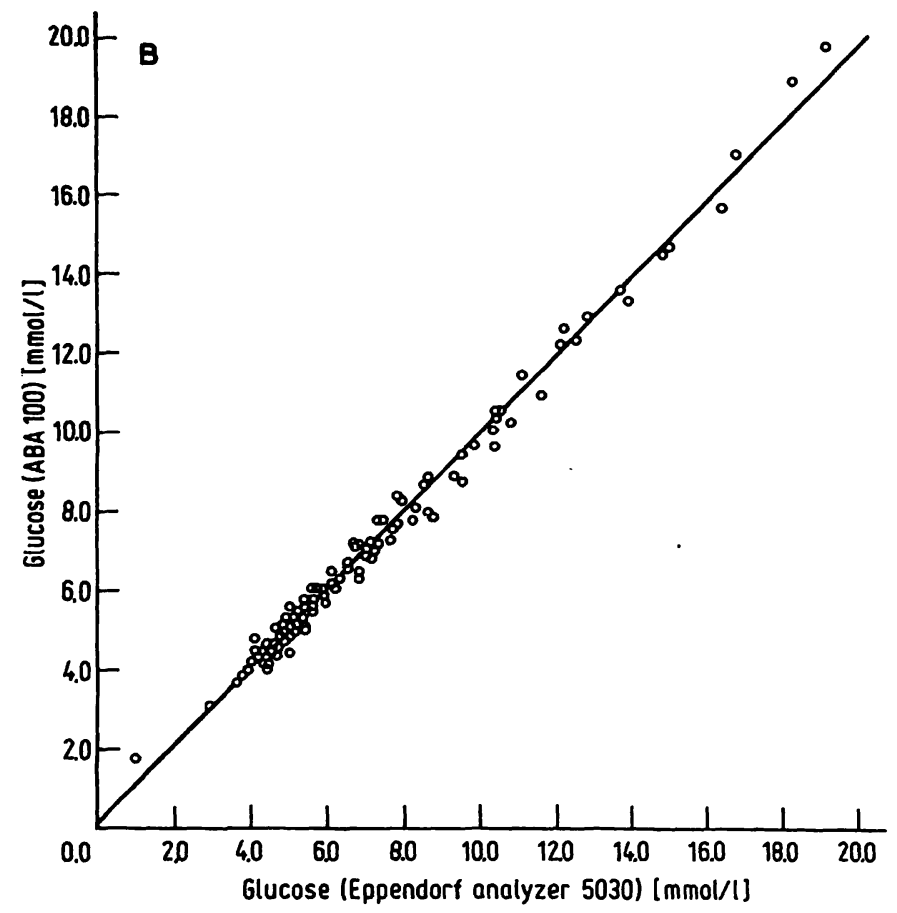

Fig. 2. Comparison of the glucose concentration in samples from various patients determined with an ABA 100, a Gemsaec and an Eppendorf analyzer 5030. ABA 100: A, C hexokinase method; B glucose dehydrogenase method. Eppendorf $(A, B)$ and Gemsaec $(C)$ analyzer: hexokinase method. Regression analysis: $\mathrm{A} y=0.9588 \mathrm{x}+0.3363$ $r=0.9931, \bar{x}=6.58 \pm 3.01, \bar{y}=6.64 \pm 2.91, n=157$, paired t-test: 2.259 . B y $=0.9888 x+0.1289, \mathrm{r}=0.9950$, $\bar{x}=6.78 \pm 3.16, \bar{y}=6.83 \pm 3.14, n=137$, paired $t$-test: 1.976. C $y=1.0070 x-0.0557, r=0.9848$, $\bar{x}=8.24 \pm 3.21, \bar{y}=8.24 \pm 3.29, n=45$, paired t-test: 0.026 .

underestimation (overcorrection at $380 \mathrm{~nm}$ ) and with 9-42 $\mathrm{g} / \mathrm{l}$ an overestimation of the glucose values was noticed, which could not be explained. At high concentrations of hemoglobin above $50 \mathrm{~g} / 1$ the low energy sign is turned on.

Triglycerides (up to $20 \mathrm{mmol} / \mathrm{l}$ ) did not interfere significantly with the applied glucose determinations (tab. 8). Glucose added to bilirubin control serum was not completely recovered (tab. 8). In the sera of patients, 
Tab. 7. The influence of hemolysis on the determination of the glucose concentration (mmol/1).

\begin{tabular}{|c|c|c|c|c|}
\hline $\begin{array}{l}\text { Patient } \\
\text { serum } \\
\text { No. }\end{array}$ & $\begin{array}{l}\text { Glucose con } \\
\text { without } \\
\text { hemolysis } \\
\text { I }\end{array}$ & $\begin{array}{l}\text { centration } \\
\text { with } \\
\text { hemolysis } \\
\text { II }\end{array}$ & $\frac{\text { II } \cdot 100}{\text { I }}$ & $\begin{array}{l}\text { hemoglobin } \\
\text { concentration } \\
\mathrm{g} / 1\end{array}$ \\
\hline
\end{tabular}

\begin{tabular}{lllll}
\hline A) Hexokinase method & & & \\
1 & 5.47 & 5.53 & 101 & 0.8 \\
& 5.47 & 5.57 & 102 & 0.7 \\
& 5.47 & 5.55 & 101 & 1.1 \\
& 5.47 & 5.52 & 101 & 0.9 \\
2 & 7.49 & 7.26 & 97 & 3.0 \\
3 & 5.8 & 6.1 & 105 & 9.0 \\
4 & 3.0 & 4.2 & 140 & 42 \\
5 & 3.0 & 3.6 & 120 & 17 \\
B) & Glucose dehydrogenase method & & \\
1 & 5.17 & 5.21 & 101 & 0.8 \\
& 5.17 & 5.17 & 100 & 0.7 \\
& 5.17 & 5.20 & 101 & 1.1 \\
& 5.17 & 5.11 & 99 & 0.9 \\
2 & 7.25 & 7.01 & 97 & 3.0 \\
3 & 5.1 & 5.4 & 106 & 9.0 \\
4 & 2.7 & 3.2 & 119 & 17 \\
5 & 2.7 & 3.8 & .141 & 41 \\
\hline
\end{tabular}

\section{Protein}

A high precision was obtained when the protein concentration was determined with the ABA 100 (tab. 1). A linear relationship between concentrations and results exists at least up to $100 \mathrm{~g} / \mathrm{l}$ protein.

The correlation between the protein content found in various control sera and assigned values is satisfactory (tab. 10).

The protein concentration was determined in various human sera with a SMA $12 / 60$ and the ABA 100. With the Technicon analyzer sample blank values were considered, but not with the ABA 100 . Therefore, the $A B A 100$ values were slightly higher than those with the SMA 12/60. Both procedures correlated well (fig. 3).

The dual wavelength principle of the ABA 100 does not completely eliminate sample blank effects with the biuret reaction. A sample blank value of about $2 \%$ (maximum $8 \%$ ) was observed with clear serum samples

Tab. 8. Recovery of glucose added to various serum samples. All values are means of at least 2 determinations with the ABA 100. I hexokinase method, II glucose dehydrogenase method.

\begin{tabular}{|c|c|c|c|c|c|c|c|}
\hline Sample & $\begin{array}{l}\text { glucose } \\
\left.1+3^{\mathrm{a}}\right) \\
\mathrm{mmol} / \mathrm{l} \\
\mathrm{I}\end{array}$ & lated & $\begin{array}{l}\text { glucose } \\
2^{\text {a) }} \\
\mathrm{mmol} / 1 \\
\mathrm{I}\end{array}$ & II & $\begin{array}{l}\text { recovery } \\
\% \\
\text { I }\end{array}$ & II & $\begin{array}{l}\text { concentration of } \\
\text { interfering substance }\end{array}$ \\
\hline $\begin{array}{l}\text { Lipemic serum No. } 1 \\
\text { Lipemic serum No. } 2 \\
\text { Bilirubin controlb) } \\
\text { Bilirubin control } \\
\text { Bilirubin control }\end{array}$ & $\begin{array}{r}14.32 \\
6.69 \\
10.62 \\
0.92 \\
9.15\end{array}$ & $\begin{array}{r}13.42 \\
6.41 \\
10.46 \\
0.94 \\
9.08\end{array}$ & $\begin{array}{r}14.35 \\
6.78 \\
10.15 \\
0.72 \\
8.87\end{array}$ & $\begin{array}{r}13.57 \\
6.26 \\
9.95 \\
0.71 \\
8.74\end{array}$ & $\begin{array}{r}100.2 \\
101.3 \\
95.6 \\
78.3 \\
96.9\end{array}$ & $\begin{array}{r}101.1 \\
97.7 \\
95.1 \\
75.5 \\
96.3\end{array}$ & $\begin{array}{l}\text { triglycerides: } 3.80 \mathrm{mmol} / 1 \\
\text { triglycerides: } 18.23 \mathrm{mmol} / 1 \\
\text { bilirubin: } 311 \mu \mathrm{mol} / 1 \\
\text { bilirubin: } 311 \mu \mathrm{mol} / 1 \\
\text { bilirubin: } 311 \mu \mathrm{mol} / 1\end{array}$ \\
\hline
\end{tabular}

a) See under methods (recovery experiments).

b) Merz \& Dade.

Tab. 9. The influence of bilirubin on the glucose determination in human sera.

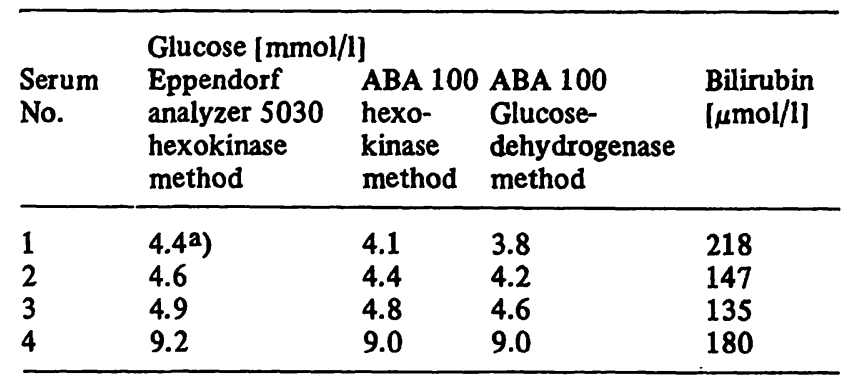

a) mmol/l, mean value of at least 2 determinations.

slightly lower glucose concentrations were found than with a deproteinization method (tab. 9). This effect can be explained as an over-correction of bilinubin which slightly absorbs at $380 \mathrm{~nm}$.

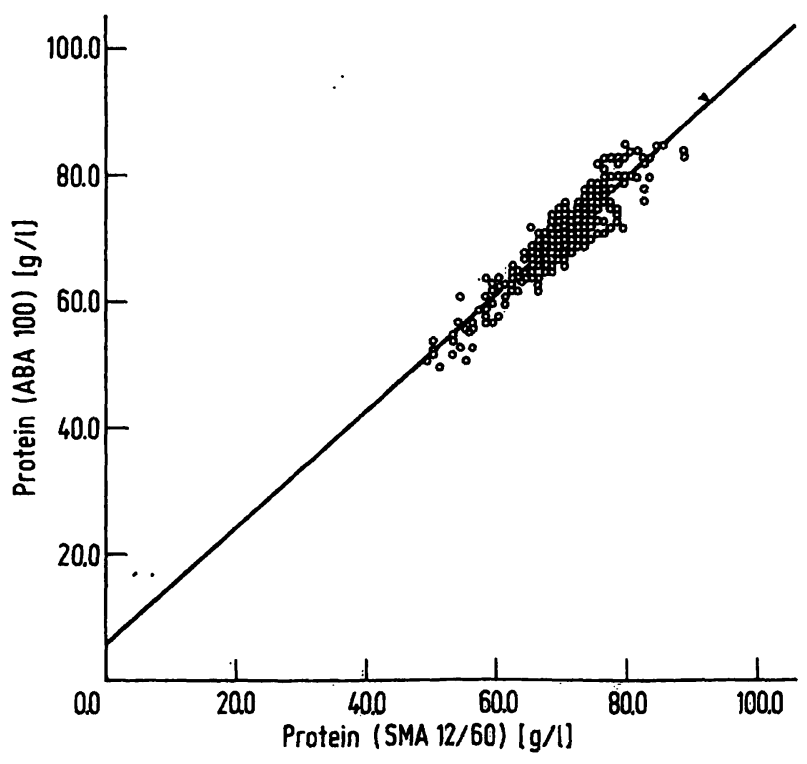

Fig. 3. Comparison of the protein concentration in various human sera determined with an ABA 100 and a SMA 12/60. Reagents for the ABA: Boehringer test combination No. 124290 . Regression analysis:

$y=0.9315 x+5.826, r=0.9262, \bar{x}=69.57, \bar{y}=70.63$, $n=322$; paired t-test: $t=-7.26$. 
Tab. 10. Precision of the protein determination with the ABA 100.

\begin{tabular}{|c|c|c|c|c|c|c|c|c|c|}
\hline \multirow{2}{*}{$\begin{array}{l}\text { Control } \\
\text { Serum } \\
\text { (batch No.) }\end{array}$} & \multirow{2}{*}{$\begin{array}{l}\text { assigned } \\
\text { value } \\
\text { (range) } \\
{[8 / 1]}\end{array}$} & \multicolumn{4}{|c|}{ precision within series } & \multicolumn{4}{|c|}{ precision from day to day } \\
\hline & & $\begin{array}{l}\bar{x} \\
{[g / 1]}\end{array}$ & $\mathbf{s}$ & $\begin{array}{l}\text { CV } \\
\text { [\%] }\end{array}$ & $\mathbf{n}$ & $\begin{array}{l}\bar{x} \\
{[g / 1]}\end{array}$ & s & $\begin{array}{l}\mathrm{CV} \\
{[\%]}\end{array}$ & $\mathbf{n}$ \\
\hline $\begin{array}{l}\text { Validate N } \\
0141014\end{array}$ & $\begin{array}{l}68 \\
(64-72)\end{array}$ & 67.8 & 0.41 & 0.6 & 12 & 67.9 & 0.95 & 1.4 & 21 \\
\hline $\begin{array}{l}\text { Europa-Kontrolle I } \\
\text { Hyland } \\
\text { VO3 }\end{array}$ & $\begin{array}{l}65 \\
(60-70)\end{array}$ & 65.2 & 0.71 & 1.1 & 13 & 65.0 & 0.89 & 1.4 & 24 \\
\hline $\begin{array}{l}\text { Europa-Kontrolle II } \\
\text { Hyland } \\
\text { VO1 }\end{array}$ & $\begin{array}{l}55 \\
(52-58)\end{array}$ & 55.0 & 0.62 & 1.1 & 13 & 55.0 & 1.00 & 1.8 & 27 \\
\hline $\begin{array}{l}\text { Seronorm } \\
124\end{array}$ & $\begin{array}{l}71 \\
(67-75)\end{array}$ & 70.4 & 0.36 & 0.5 & 13 & 70.3 & 0.64 & 0.9 & 27 \\
\hline $\begin{array}{l}\text { Kontrollogen } \\
410\end{array}$ & $\begin{array}{l}61 \\
(57-65)\end{array}$ & 64.1 & 0.37 & 0.6 & 13 & 64.1 & 0.83 & 1.3 & 27 \\
\hline $\begin{array}{l}\text { Monitrol II } \\
38 \mathrm{~A}, \mathrm{~B}\end{array}$ & $\begin{array}{l}57 \\
(54-60)\end{array}$ & 56.4 & 0.44 & 0.8 & 14 & 56.4 & 0.66 & 1.2 & 29 \\
\hline $\begin{array}{l}\text { Monitrol I } \\
130 \mathrm{~A}, \mathrm{~B}\end{array}$ & $\begin{array}{l}72.5 \\
(69-76)\end{array}$ & 72.3 & 0.50 & 0.7 & 13 & 72.4 & 1.09 & 1.5 & 29 \\
\hline
\end{tabular}

Regression analysis: $y=0.96 x+2.92, \bar{x}$ (assigned values) $=64.2, \bar{y}$ (mean value from day to day) $=64.4 ; r=0.98(n=14)$.

Tab. 11. Determination of the protein concentration $(g / 1)$ in lipemic and hemolytic sera with the ABA 100. Calibration: with protein standard solution ORTH $16 / 17$ from Behringwerke. Each value is a mean of 2 determinations.

\begin{tabular}{lllll}
\hline Serum & $\begin{array}{l}\text { protein } \\
\text { blank value } \\
\text { not considered } \\
\text { [g/1] }\end{array}$ & $\begin{array}{l}\text { concentration } \\
\text { blank value } \\
\text { subtracted } \\
{[\mathrm{g} / \mathrm{l}]}\end{array}$ & deviation & $\begin{array}{l}\text { concentration of } \\
\text { interfering substance }\end{array}$ \\
\hline Serum No. 1 & 76.4 & 67.4 & +13 & \\
Serum No. 2 & 74.6 & 65.2 & +14 & triglycerides: $5.25 \mathrm{mmol} / 1$ \\
Serum No. 3 & 82.3 & 69.4 & +19 & triglycerides: $5.87 \mathrm{mmol} / 1$ \\
Serum No. 4 & 90.2 & 74.8 & +21 & triglycerides: $5.12 \mathrm{mmol} / 1$ \\
Serum No. 5a) & 75.6 & 66.0 & +15 & hemoglobin: $2 \mathrm{~g} / 1 \mathrm{mmol} / 1$ \\
Serum No. 5 & 69.2 & 65.0 & +6 & not hemolytic \\
Serum No. 6 & 83.7 & 69.9 & +20 & hemoglobin: $10 \mathrm{~g} / 1$ \\
Serum No. 6 & 63.9 & 61.6 & +4 & not hemolytic \\
Bilirubin controlb) & 112.0 & 109.9 & +2 & bilinubin: $335 \mu \mathrm{mol} / 1$ \\
Biliubin control & 54.9 & 54.0 & +2 & bilirubin: $168 \mu \mathrm{mol} / 1$ \\
Albumin solution & 68.5 & 68.3 & - & albumin: $70 \mathrm{~g} / \mathrm{l}$ \\
\hline
\end{tabular}

a) blood samples No. 5-6 were split, one half was centrifugated directly, the other part after artificial hemolysis (see under methods).

b) bilirubin control (Merz \& Dade) dissolved in $1.5 \mathrm{ml}$ instead of $3.0 \mathrm{ml}$ double distilled $\mathrm{H}_{2} \mathrm{O}$.

and should be considered for very accurate measurements or with lipemic and hemolytic sera (tab.11). Bilirubin did not interfere significantly.

The biuret assay was used to check carry-over effects. For this purpose 3 samples with $10 \mathrm{~g} / \mathrm{l}$ albumin, 3 with $100 \mathrm{~g} / \mathrm{l}$ and again 3 with $10 \mathrm{~g} / \mathrm{l}$ were consecutively analyzed. A significant interaction (6) could not be detected.

\section{Aminotransferase}

The activity of both alanine and aspartate aminotransferase was determined in several control sera and in the sera of 200 patients with the ABA 100 and the results were compared with those obtained with an Eppendorf enzyme analyzer 5010. The precision from day to day ranged from 4 to $9 \%$ above an activity of $15 \mathrm{U} / 1$ (tab. 12). The regression analysis revealed an acceptable congruence between the data found with the $\mathrm{ABA}$ and the assigned values (tab. 12) or those determined with the enzyme analyzer 5010 (fig. 4; a similar correlation was obtained in 16 samples with activity values of up to $1000 \mathrm{U} / 1$ ).

\section{Creatine kinase}

The creatine kinase was used as an example for the determination of an enzyme activity with increasing 
Tab. 12. Precision of the determination of enzyme activities in various control sera with the ABA 100 .

\begin{tabular}{|c|c|c|c|c|c|c|c|c|}
\hline Control serum & (batch No.) & $\begin{array}{l}\text { assigned value } \\
\text { (range) } \\
\text { [U/1] }\end{array}$ & $\begin{array}{l}\text { precisi } \\
\overline{\bar{X}} \\
{[U / 1 /}\end{array}$ & $\begin{array}{l}\text { withi } \\
\text { CV } \\
\text { [\%] }\end{array}$ & $\begin{array}{l}\text { ries } \\
\text { (n) }\end{array}$ & $\begin{array}{l}\text { from } \\
\bar{x} \\
{[U / 1]}\end{array}$ & $\begin{array}{l}\text { to day } \\
\text { CV } \\
\text { [\%] }\end{array}$ & (n) \\
\hline \multicolumn{9}{|c|}{ a) aspartate aminotransferase } \\
\hline $\begin{array}{l}\text { Monitrol I } \\
\text { Monitrol II } \\
\text { Kontrollogen L } \\
\text { Hyland VO1 } \\
\text { Seronorm }\end{array}$ & $\begin{array}{l}(124) \\
(32) \\
(410) \\
(124)\end{array}$ & $\begin{array}{c}13(11-15) \\
37(33-41) \\
25(22-28) \\
34(30-38) \\
131(125-137)\end{array}$ & $\begin{array}{r}39 \\
25 \\
34 \\
124\end{array}$ & $\begin{array}{l}2.1 \\
3.1 \\
2.9 \\
2.6\end{array}$ & $\begin{array}{l}(31) \\
(32) \\
(30) \\
(31)\end{array}$ & $\begin{array}{r}12 \\
39 \\
25 \\
131\end{array}$ & $\begin{array}{l}6.9 \\
5.5 \\
4.1 \\
\\
5.4\end{array}$ & $\begin{array}{l}(13) \\
(12) \\
(12) \\
(11)\end{array}$ \\
\hline \multicolumn{9}{|c|}{ b) alanine aminotransferase } \\
\hline $\begin{array}{l}\text { Monitrol I } \\
\text { Monitrol II } \\
\text { Kontrollogen L } \\
\text { Seronorm } \\
\text { Seronorm }\end{array}$ & $\begin{array}{l}(124) \\
(32) \\
(410) \\
(126) \\
(124)\end{array}$ & $\begin{array}{l}15(13-17) \\
69(64-74) \\
32(29-35) \\
55(50-60) \\
59(53-65)\end{array}$ & $\begin{array}{l}70 \\
33 \\
60\end{array}$ & $\begin{array}{l}4.1 \\
3.6 \\
\\
3.0\end{array}$ & $\begin{array}{l}(30) \\
(30) \\
(31)\end{array}$ & $\begin{array}{l}14 \\
68 \\
34 \\
53\end{array}$ & $\begin{array}{l}8.9 \\
6.6 \\
5.9 \\
6.4\end{array}$ & $\begin{array}{l}(10) \\
(11) \\
(12) \\
(12)\end{array}$ \\
\hline \multicolumn{9}{|l|}{ c) creatine kinase } \\
\hline $\begin{array}{l}\text { Kontrollogen L } \\
\text { Hyland VO1 } \\
\text { Hyland VO4 } \\
\text { Monitrol II } \\
\text { Validate N }\end{array}$ & $\begin{array}{l}(32) \\
(0141014)\end{array}$ & $\begin{array}{c}26(18-34) \\
180(100-260) \\
204(158-250) \\
100(82-118) \\
15(13-17)\end{array}$ & $\begin{array}{r}26 \\
183 \\
206 \\
101 \\
12\end{array}$ & $\begin{array}{l}4.6 \\
1.4 \\
1.7 \\
2.0 \\
8.3\end{array}$ & $\begin{array}{l}(31) \\
(31) \\
(12) \\
(31) \\
(31)\end{array}$ & $\begin{array}{r}26 \\
205\end{array}$ & $\begin{array}{l}7.5 \\
3.7\end{array}$ & $\begin{array}{l}\text { (15) } \\
\text { (12) }\end{array}$ \\
\hline \multicolumn{9}{|c|}{ d) hydroxybutyrate dehydrogenase } \\
\hline $\begin{array}{l}\text { Validate N } \\
\text { Seronorm } \\
\text { Kontrollogen L } \\
\text { Hyland VO1 } \\
\text { Hyland VO4 } \\
\text { Monitrol I } \\
\text { Monitrol II }\end{array}$ & $\begin{array}{l}(2991103) \\
(124) \\
(410)\end{array}$ & $\begin{array}{c}80(66-94) \\
239(216-262) \\
90(80-100) \\
185(160-210) \\
68(58-78) \\
92(75-109) \\
269(247-291)\end{array}$ & $\begin{array}{r}79 \\
252 \\
92 \\
208 \\
71 \\
87 \\
268\end{array}$ & $\begin{array}{l}2.4 \\
1.1 \\
3.4 \\
2.2 \\
3.2 \\
3.7 \\
1.9\end{array}$ & $\begin{array}{l}(14) \\
(14) \\
(14) \\
(14) \\
(14) \\
(14) \\
(14)\end{array}$ & $\begin{array}{r}78 \\
251 \\
92 \\
208 \\
71 \\
88 \\
285\end{array}$ & $\begin{array}{l}5.6 \\
6.8 \\
4.0 \\
6.0 \\
9.1 \\
7.2 \\
7.3\end{array}$ & $\begin{array}{l}(7) \\
(7) \\
(7) \\
(7) \\
(7) \\
(7) \\
(7)\end{array}$ \\
\hline \multicolumn{9}{|c|}{ e) alkaline phosphatase } \\
\hline $\begin{array}{l}\text { Seronorm } \\
\text { Hyland VO4 } \\
\text { Hyland VO1 } \\
\text { Monitrol II } \\
\text { Monitrol I }\end{array}$ & $\begin{array}{l}(32) \\
(124)\end{array}$ & $\begin{array}{c}241(217-265) \\
63(52-74) \\
108(90-126) \\
194(174-214) \\
65(51-79)\end{array}$ & & & & $\begin{array}{r}218 \\
57 \\
115 \\
202 \\
57\end{array}$ & $\begin{array}{l}1.7 \\
3.6 \\
2.8 \\
3.8 \\
4.6\end{array}$ & $\begin{array}{l}(15) \\
(15) \\
(15) \\
(15) \\
(15)\end{array}$ \\
\hline
\end{tabular}

Regression analysis ( $x=$ assigned values, $y=$ found values): aspartate aminotransferase $y=1.01 x=0.51(x=41.3, \bar{y}=41.2)$, $\mathrm{r}=0.996$; alanine aminotransferase $y=1.01 x-0.75 \bar{x}=35.5, \bar{y}=35.0, r=0.999 ;$ creatine kinase $y=1.03 x=4.14(\bar{x}=95.8$, $\bar{y}=94.7), r=0.999$; hydroxybutyrate dehydrogenase $y=1.10 x-6.57(\bar{x}=146, \bar{y}=152), r=0.998$; alkaline phosphatase $y=0.95 x+1.83(x=134, \bar{y}=130), r=0.987$.
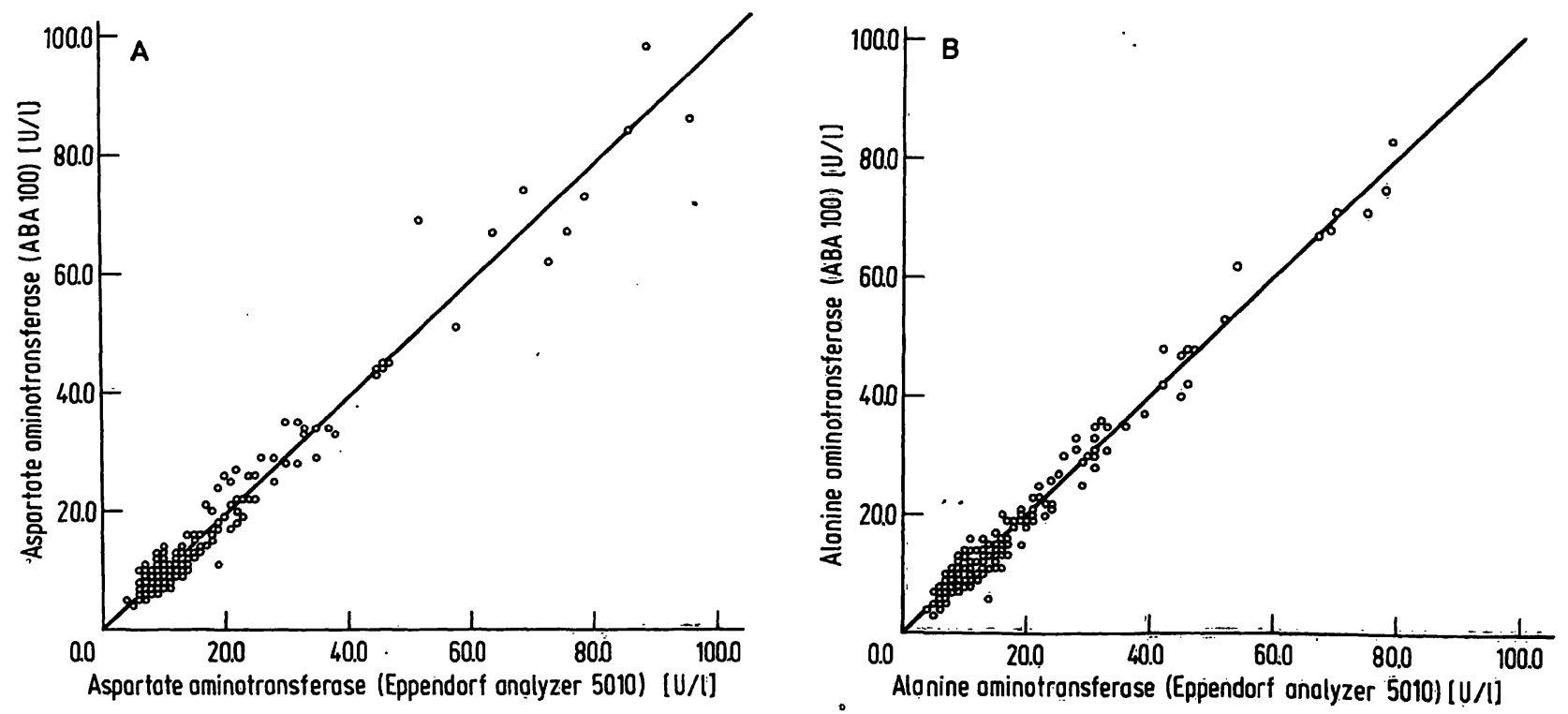

Fig. 4. Comparison of the aminotransferase activities in various human sera determined with an $A \dot{B A} 100$ and an Eppendorf enzyme analyzer 5010. A: aspartate aminotransferase (GOT), regression analysis: $y=0.9743 x=0.0873, \bar{x}=17.6, \bar{y}=17.1$, $r=0.9853(n=202)$. B: alanine aminotransferase $(G P T)$, regression analysis: $y=1.0009 x+0.0356, \overline{\bar{x}}=17.3, \bar{y}=1.7 .4$, $\mathrm{r}=0.9877(\mathrm{n} \doteq 196)$. 

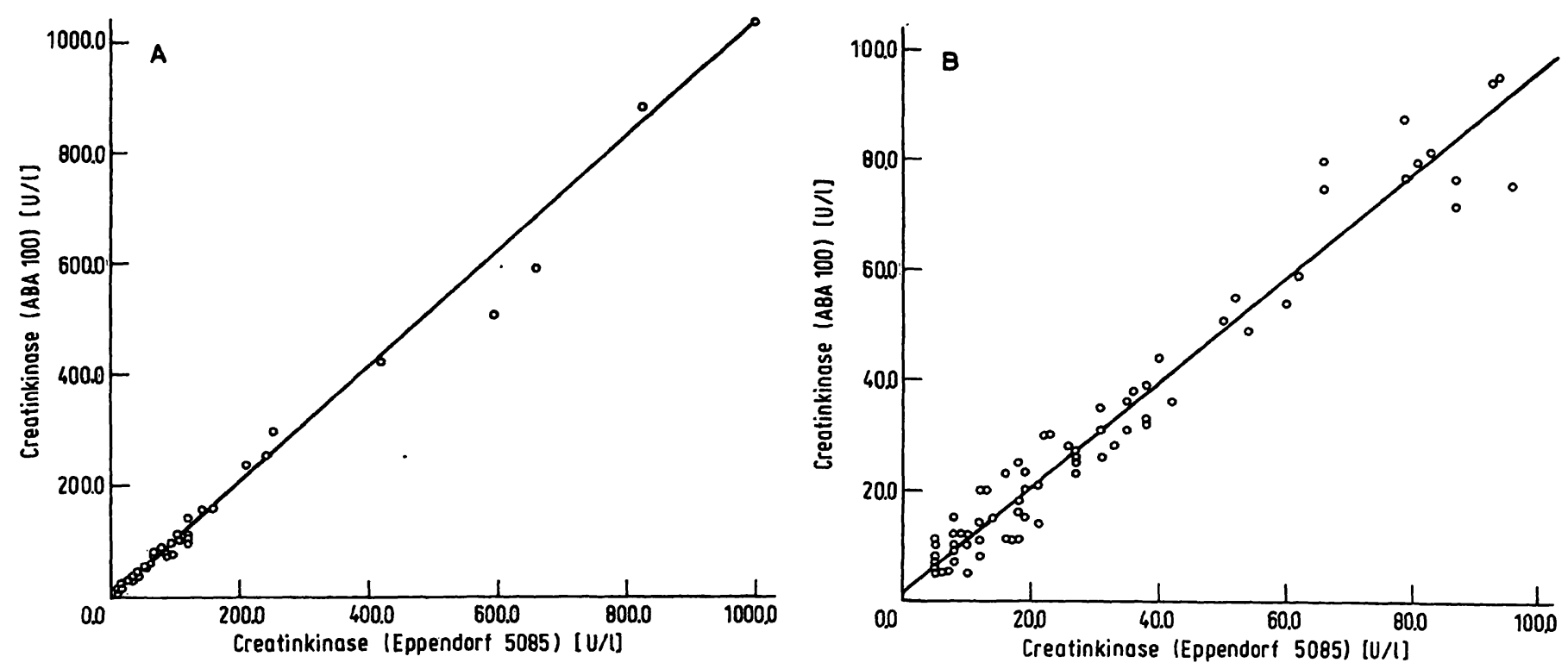

Fig. 5. Comparison of the creatine kinase activity in various human sera determined with an ABA 100 and a partly mechanized procedure (Eppendorf No. 5085). Reagents: Boehringer test combination No. 124184. Regression analysis: $A y=0.9509 x+1.3361, r=0.9804, \bar{x}=27.2 \pm 25.7, \bar{y}=27.2 \pm 24.9, n=86 . B y=1.0354 x-1.7273, r=0.9932$, $\bar{x}=75.7 \pm 154.5 . \bar{y}=76.6 \pm 161.1, n=107$.

absorbance. The precision from day to day varied from 3.7 to $7.6 \%$ (tab. 12). Figure 5 shows the correlation of several activity values determined in the sera of patients with the ABA 100 and with a partly mechanized Eppendorf system 5085.

\section{Lactate and hydroxybutyrate dehydrogenase}

The typical mode of operation for the determination of enzyme activities is to take a first reading after a 5 minute incubation period and then a second reading after further 5 minutes. The results are calculated from the difference between both values.

As expected the lactate dehydrogenase activity values were usually $7 \%$ lower than those determined with an Eppendorf analyzer 5010, since the reaction is not recorded under the conditions of a zero order reaction. The fast kinetic reaction mode overcomes this problem, but it cannot be recommended for routine purposes; the through-put rate would be $15-30$ samples per hour leading to 3 results for each patient, which then have to be compared.

The activity of the hydroxybutyrate dehydrogenase can be determined with the ABA 100. Precision data with several control sera are summarized in table 12 .

\section{Alkaline phosphatase}

The alkaline phosphatase was chosen for evaluating. determinations at $450 / 415 \mathrm{~nm}$ with the $\mathrm{ABA} 100$. The precision data are listed in table 12 . Comparing results from the sera of patients, the ABA 100 values were about 7\% higher than those determined with an Eppendorf analyzer 5010 (fig. 6). The same effect was observed with the $\gamma$-glutamyltransferase (fig. 7). The reason for this discrepancy was not investigated.

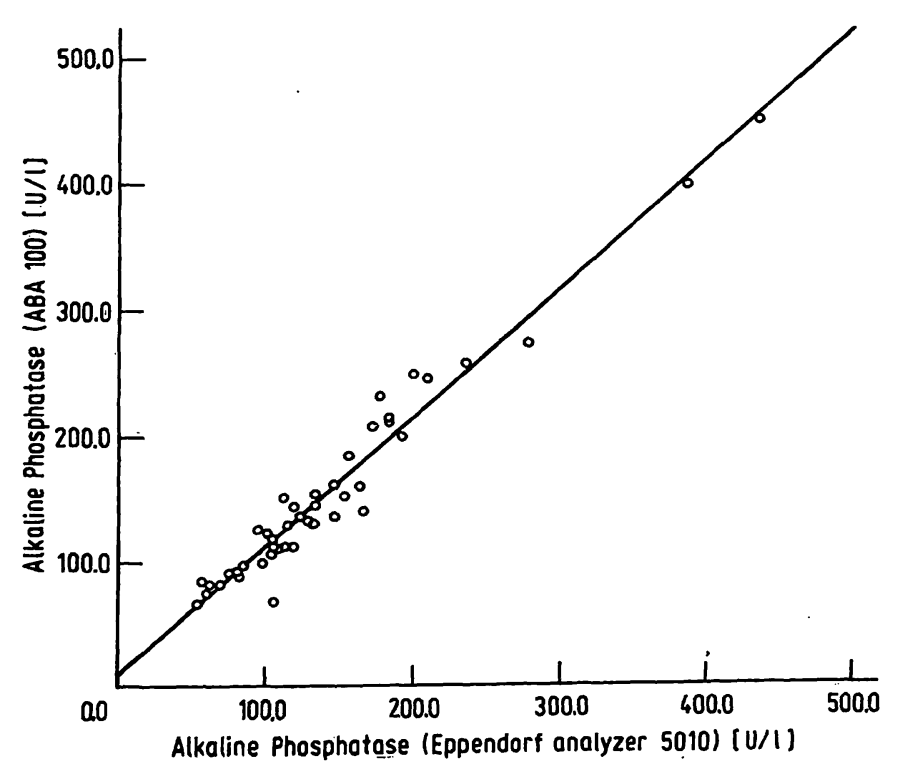

Fig. 6. Comparison of the alkaline phosphatase activity in various human sera determined with an $A B A 100$ and an Eppendorf analyzer 5010. Reagents: Boehringer test combination No. $123862(20 \mathrm{ml}$ solution $\mathrm{I}+2 \mathrm{ml}$ solution II). Regression analysis:

$y=1.0392 x+8.4169, \bar{x}=140, \bar{y}=154, r=0.9764$ ( $m=46$ pairs). 


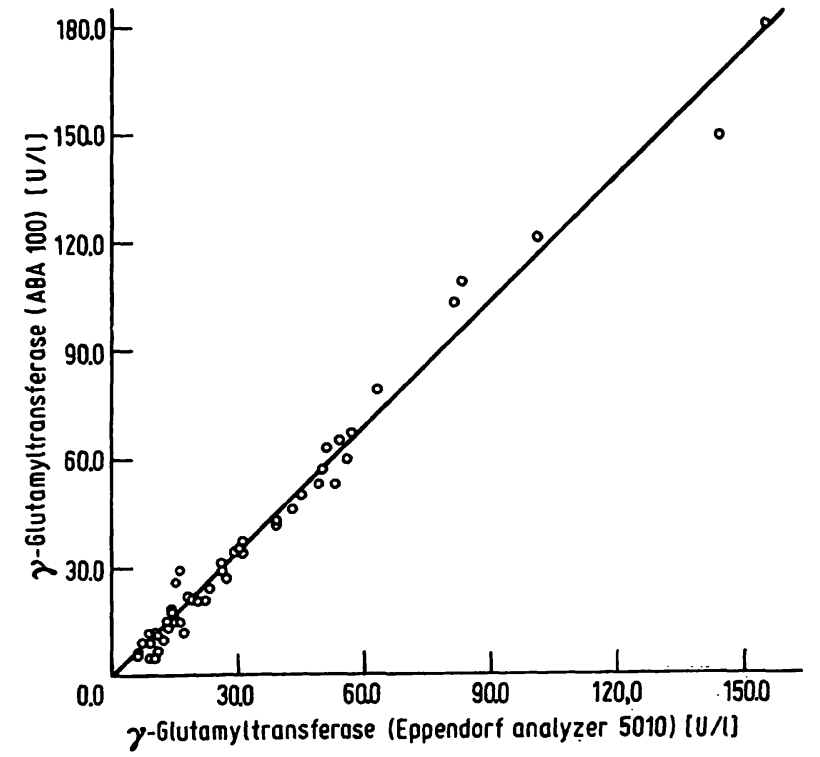

Fig. 7. Comparison of the $\gamma$-glutamyltransferase activity in various human sera determined with an ABA 100 and an Eppendorf enzyme analyzer 5010. Reagents: Boehringer test combination No. 124702. Regression analysis: $y=1.15 x-0.59, r=0.99, \bar{x}=33.15 \pm 31.15, \bar{y}=37.69$ $\pm 36.75, \mathrm{n}=54$; paired $\mathrm{t}$-test: $\mathrm{t}=-4.86(\mathrm{p}<0.01)$.

\section{Economical aspects}

The critical batch size is a term recently introduced to indicate the cost-benefit relation of an analyzer in comparison with a manual or less mechanized analytical system $(9,10)$. If the number of samples to be analyzed per day is below the critical batch size $n_{k}$, the mechanized system is less economical; if it is above this figure, mechanization is to be preferred. Factors influencing the critical batch size were discussed in detail elsewhere (10).

In comparison with other analyzers (9) a relatively low critical batch size was calculated for the ABA 100 as shown by the example in table 13. If a series of glucose determinations of more than $\mathbf{4 0}$ samples are daily performed the $\mathrm{ABA} 100$ is more economical than a manual procedure.

\section{Aspects of subjective judgement}

Advantages of general interest may be: a low error rate (tab. 14); only a few minutes are necessary to switch from one method to another one (about

Tab. 13. The critical batch size $\left(n_{k}\right)$ of the ABA 100 in comparison with a manual procedure of the glucose determination. Reagents: Boehringer test combination No. 124346. For explanation of the calculation steps see Ref. 9 and 10.

\begin{tabular}{|c|c|c|c|}
\hline & & manual procedure ${ }^{1}$ ) & ABA 100 \\
\hline \multicolumn{4}{|l|}{ A) fixed costs } \\
\hline I purchase prize & $(\mathrm{DM})$ & 17554.65 & $\left.64345.59^{2}\right)$ \\
\hline II $1.5 \%$ of I & (DM) & 263.32 & 965.18 \\
\hline III one-way material per series & (DM) & 0.73 & 0.26 \\
\hline IV costs for reagents per series & & 0.75 & - \\
\hline$c_{f}=(I+I I \times 5): 1500+I I I+I V$ & (DM) & 14.06 & 46.37 \\
\hline \multicolumn{4}{|l|}{ B) variable costs: } \\
\hline I one-way material per sample & $(\mathrm{DM})$ & 0.27 & $\left.0.18^{3}\right)$ \\
\hline II costs for reagents & (DM) & 0.15 & 0.14 \\
\hline III time of analysis $t_{1}$ & $(\min )$ & $\left.56(10 \text { samples) })^{4}\right)$ & 28 (29 samples) $)^{5}$ \\
\hline$t_{2}$ & $(\min )$ & $289{\left.\text { (100 samples })^{4}\right)}^{4}$ & 140 (145 samples) $\left.)^{5}\right)$ \\
\hline $\mathrm{n}_{\mathrm{k}}$ & & - & 40 \\
\hline
\end{tabular}

1) Eppendorf photometer 1101, pump 5260, centrifuge 3200, dispenser 5211, diluter 5232.

2) Eppendorf pipet included.

3) Cost for multicuvet/29 samples.

$\left.{ }^{4}\right)$ Each series contains 3 blanks, 1 standard and 1 control sample.

5) Each multicuvet contains 1 sample, 1 standard and 1 control sample.

Tab. 14. Technical errors of an ABA 100 during a one-year evaluation period (approximately 500 runs).

\begin{tabular}{|c|c|c|}
\hline Type of error & $\begin{array}{l}\text { defect part sent } \\
\text { to the manufacturer }\end{array}$ & $\begin{array}{l}\text { Service } \\
\text { called }\end{array}$ \\
\hline $\begin{array}{l}\text { 1. Filter 380/340: defect } \\
\text { 2. Syringe plate 1:101: dilution factor deviated more than } 5 \% \text { from the declared value } \\
\text { 3. Syringe plate } 1: 101 \text { : valve defect after a } 6 \text { months operation period } \\
\text { 4. Carousel overjumped some positions } \\
\text { 5. Sample pick-up had to be adjusted } \\
\text { 6. During print-out of results the instrument stopped, before all data were received. } \\
\text { This happened } 4 \text { times; the cause was not investigated. }\end{array}$ & $\begin{array}{l}+ \\
+ \\
+\end{array}$ & $\begin{array}{l}+ \\
+\end{array}$ \\
\hline
\end{tabular}


1.5 minutes to interchange the syringe plate and 1 minute for all other operations required to start the analyzer); the complete pipetting system (syringe plate) can be stored in a refrigerator; a relatively small space is required for installation (length $100 \mathrm{~cm}$, depth $60 \mathrm{~cm}$, height $61 \mathrm{~cm}$ ); and the analyzer is easy to operate.

The instrument appears very suited for the determination of substrate concentrations if a one-reagent procedure can be applied, as e.g. glucose and protein. Reports on bilirubin ((11), Evelyn-Malloy modification), cholesterol (12) and triglyceride procedures (13) have recently been published. Methods requiring 2 reagents which have to be added separately (determination of urea with the urease-Berthelot procedure, or of bilirubin according to Jendrassik \& Grof) or methods with sub- traction of a blank reaction cannot be performed with the ABA 100.

A further disadvantage of the ABA 100 is its inability to measure absolute values of absorbance; these can only be obtained by using $\frac{6.22}{\mathrm{FF}} \times 0.5$ as the calibration factor. Filter factors (FF) supplied by the manufacturer, or determined, or checked by the customer can be obtained only indirectly by a series of experiments with standard materials.

Enzyme activities are determined by a two-point measurement of absorbance. This procedure can be accepted for those enzymes which are most commonly used in clinical chemistry, except for lactate dehydrogenase.

\section{References}

1. Broughton, P. M. G., Gowenlock, A. H., Mac Cormack, J. J. \& Neil, D. W. (1974), Ann. Clin. Biochem. 11, 207-218.

2. Haeckel, R. \& Haeckel, H. (1972), this j. 10, 453-461.

3. Haeckel, R. (1973), this j. 11, 243-248.

4. Standardisierung von Methoden zur Bestimmung von Enzymaktivitäten in biologischen Flüssigkeiten (1972), this j. 10, 182-192.

5. Kramer, D. \& Porth, A. J. (1975), Ärztl. Lab. 20, 413 $-417$.

6. Haeckel, R., Qualitätssicherung im medizinischen Laboratorium (1975), Deutscher Ärzteverlag, Köln, 1-237.

7. Banauch, D., Brümmer, W., Ebeling, W., Metz, H., Rindfrey, H., Lang, H., Leybold, K. \& Rick, W. (1975), this j. 13,101-107.

8. Gochmann, N., Ryan, W. T., Sterling, R. E. \& Widdowson, M. (1975), Clin. Chem. 21, 356-361.

9. Haeckel, R., Höpfel, P. \& Höner, G. (1974), this j. 12, 17-22.

10. Haeckel, R. (1975), Med. Progr. Technol. 3, 65-71.

11. Jaberg, C., McConnell, K., Potter, J. L. \& Platt, M. S. (1975), Clin. Chem. 21, 1511-1512.

12. Witte, D. L., Barrett II, D. A. \& Wycoff, D. A. (1974), Clin. Chem. 20, 1282-1286.

13. Sampson, E. J., Demers, L. M. \& Krieg, A. F. (1975), Clin. Chem. 21, 1983-1985.

Prof. Dr. R. Haeckel Institut für Klinische Chemie Karl-Wiechert-Allee 9 D-3000 Hannover 61 
